\title{
KARAKTERISASI SERAT DARI TANAMAN BIDURI (Calotropis gigantea) DAN IDENTIFIKASI KEMUNGKINAN PEMANFAATANNYA SEBAGAI SERAT TEKSTIL
}

\author{
CHARACTERIZATION OF THE FIBER FROM BIDURI \\ (Calotropis gigantea) AND THE IDENTIFICATION OF IT'S UTILIZATION \\ POSSIBILITY AS A TEXTILE FIBER
}

\author{
M. Danny Sukardan, Dikdik Natawijaya, Puri Prettyanti, Cahyadi, Eva Novarini
}

Balai Besar Tekstil, Jalan Jenderal Ahmad Yani No. 390 Bandung

E-mail: texirdti@bdg.centrin.net.id

Tanggal diterima: 14 Desember 2016, direvisi: 8 Maret 2017, disetujui terbit: 22 Maret 2017

\begin{abstract}
ABSTRAK
Calotropis gigantea atau yang dikenal dengan nama Biduri merupakan tanaman perdu/ilalang yang dapat tumbuh liar di pesisir pantai, dataran tinggi bahkan di lokasi tanah keras dan berkapur. Di bagian dalam buahnya terdapat serat halus yang berpotensi untuk dijadikan bahan baku serat tekstil. Untuk mengetahui karakteristik dan potensi pemanfaatannya, pada penelitian ini dilakukan karakterisasi berdasarkan morfologi, sifat kimia, fisika dan mekanik serta uji pemintalan. Sampel Calotropis gigantea yang digunakan diambil dari Semarang, Pangandaran, Ciamis, Cilacap dan Yogyakarta. Untuk pembanding, dilakukan pula pengamatan pada serat kapas dan kapok. Berdasarkan pengamatan diketahui bahwa morfologi serat Calotropis gigantea berbentuk hollow (berongga) dengan volume hollow 92,3 - 94,7 \% dan rendemen serat 8,9\% dari berat buah. Kandungan selulosa 66,52 - 71,62 \%; lignin 13,45 - 14,08 \%; kadar air (MC 7,3 \%; MR 7,9 \%); rasio daya serap minyak : air 60,89 kali (g/g) dan 57,06 kali $\left(\mathrm{g} / \mathrm{cm}^{3}\right)$. Sifat fisika Calotropis gigantea : panjang $\pm 1,25$ inchi; kerataan panjang 84,0; kekuatan per berkas 37,8 g/tex; efek kilau tinggi (+b 19,6); indeks serat pendek 7,8; mulur rendah (3,9 \%); ringan dan halus $(2,02 \mu)$; kaku; permukaan licin; mengapung di air dan minyak (buoyant). Hasil uji pemintalan $100 \%$ Calotropis gigantea menunjukkan bahwa kualitas benang masih di bawah standar mutu benang ring tenun (carded) kapas $100 \%$ (SNI 08-0033-2006). Berdasarkan hasil pengamatan dan penelitian, serat dari buah Calotropis gigantea memiliki karakteristik potensial sebagai bahan tekstil seperti filler untuk material pengapung dan penyerap tumpahan minyak.
\end{abstract}

Kata kunci: Calotropis gigantea, biduri, serat hollow, penyerap minyak, daya apung

\section{ABSTRACT}

Calotropis gigantea, or known as Biduri is classified as shrubs/reeds that grow wildly along the coast, the highlands and even on hard and calcareous soil. Inside of the fruit there are fine fibers that possibly potential to be utilized as a raw material for textile fiber. In order to investigate the characteristics and potential of it's utilization, in this research the Calotropis gigantea fiber were characterized by their morphology, chemical, physical and mechanical properties, as well as spinning trials. Calotropis gigantea samples were taken from Semarang, Pangandaran, Ciamis, Cilacap and Yogyakarta. As for comparison, observations also made on cotton and kapok fiber. The observations revealed that the fiber morphology is hollow fiber with hollow volume $92.3-94.7 \%$ and the fiber yield $8.9 \%$ of weight of the fruit. Cellulose content 66.52 to $71.62 \%$; lignin content 13.45 to $14.08 \%$; moisture content (MC $7.3 \%$; MR $7.9 \%$ ); absorption ratio of oil : water 60.89 times $(\mathrm{g} / \mathrm{g})$ and 57.06 times $(\mathrm{g} / \mathrm{cm} 3)$. Physical properties of Calotropis gigantea : fiber length \pm 1.25 inches; length uniformity 84.0; tensile strength 37.8 g/tex; high luster (+ $b$ 19.6); low short fiber index 7.8; elongation $3.9 \%$; light and fine (2.02 $\mu)$; rigid; smooth surface; floating on water and oil (buoyant). The spinning test results of $100 \%$ Calotropis gigantea indicates that the yarn quality is still beneath the quality of the standard woven ring yarn (carded) cotton $100 \%$ (SNI 08-00332006). Based on the observations and research, Calotropis gigantea fiber has a potential textile material characteristics such as filler for floatation (buoyancy) material and oil spill absorbent.

Keywords: Calotropis gigantea, biduri, hollow fiber, oil absorbent, buoyancy properties 


\section{PENDAHULUAN}

Industri tekstil dan produk tekstil (industri TPT) adalah salah satu industri perintis dan tulang punggung sektor industri di Indonesia. Industri ini merupakan salah satu dari sepuluh klaster industri inti yang menjadi prioritas pengembangan dalam jangka panjang sebagaimana tercantum pada Peraturan Presiden No. 7 tahun 2005. ${ }^{1}$ Gambar 1 menyajikan data neraca perdagangan tekstil dan produk tekstil tahun 2015. Dari gambar tersebut terlihat bahwa neraca perdagangan untuk serat dan kain adalah defisit, sedangkan untuk neraca perdagangan benang, pakaian jadi, permadani dan barang jadi tekstil masih surplus. ${ }^{2}$ Jenis serat tekstil yang paling banyak diimpor diantaranya adalah serat kapas, rayon dan poliester.

Selama kurun waktu dekade terakhir ini, Pemerintah melalui Kementerian Perindustrian mencoba menggali potensi sumber daya alam Indonesia yang dikenal dengan istilah SANT (Serat Alam Non Tekstil) seperti serat nanas, serat kapuk, serat kelapa, serat pisang, serat dari ulat doyo dan lain sebagainya untuk dijadikan sebagai bahan baku tekstil dan produk tekstil. Meski kualitas SANT masih sulit untuk memenuhi persyaratan bahan baku tekstil sandang, namun SANT ini berpotensi besar sebagai bahan baku tekstil nonsandang/tekstil teknik atau tekstil fungsional lainnya. ${ }^{3}$

Indonesia merupakan salah satu negara tropis dengan tingkat keanekaragaman hayati [biodiversity] terbesar di dunia. Banyak sekali potensi kekayaan alam Indonesia yang dapat dimanfaatkan untuk mendukung ketersediaan sumber daya sebagai salah satu elemen pendorong peningkatan daya saing industri. Salah satunya adalah pemanfaatan sumber daya alam Indonesia untuk mensubsitusi bahan baku/bahan penolong di industri TPT yang selama ini harus dipenuhi melalui jalur impor. Hal inilah yang dijadikan sebagai dasar pertimbangan penulis untuk meneliti potensi pemanfaatan tanaman Calotropis gigantea yang tumbuh liar di Indonesia untuk bahan baku tekstil dan produk tekstil.
Tanaman Calotropis gigantea di Indonesia dikenal dengan nama Biduri atau Widuri. Tanaman ini merupakan tanaman asli Asia Tenggara yang mudah didapatkan di Indonesia, Filipina, Kamboja, Malaysia, Thailand, Srilanka, India dan China. ${ }^{4,5} \mathrm{Di}$ daerah lain di Indonesia dikenal dengan nama-nama Rubik, Biduri (Sunda, Madura); Lembega, Rembega, Rumbigo (Sumatera); Badori, Widuri, Saduri, Sidoguri, Burigha (Jawa); Manori, Maduri (Bali); Muduri, Rembiga, Kore, Krokoh, Modo, Kapauk, Modo Kampauk (Nusa Tenggara); Rambega (Sulawesi).Tanaman ini dikenal sebagai tanaman obat dengan kulit akar, bunga, getah dan daun yang memiliki khasiat berbeda-beda, serta memiliki buah berisi berkas-berkas serat halus seperti sutera yang melekat pada setiap bijinya. ${ }^{6}$

Tanaman perdu lain di dunia yang sudah banyak dikembangkan dan dimanfaatkan sebagai produk akhir yang dikenal dengan nama Milkweed fibers berasal dari jenis Asclepia syriaca. Tanaman ini juga disebut sebagai serat sutera dari tumbuhan (bukan serat protein) yang memiliki kesamaan penampilan dengan serat Rux (Caleotropis gigantea) yang tumbuh subur di kawasan Asia Tenggara. ${ }^{7,8}$

Tanaman Calotropis gigantea merupakan salah satu jenis belukar/tanaman perdu yang dapat tumbuh mencapai setinggi 3 meter. Serat dapat diperoleh dari kulit batang dan biji buahnya. Getah warna putih menyerupai susu yang keluar dari batang tanaman diketahui bermanfaat untuk kesehatan, diantaranya sebagai obat herbal penyakit pusing, asma, bronkitis, dispepsia, lepra, tumor dan berbagai penyakit gangguan pencernaan. ${ }^{9}$ Pada Gambar 2 sampai dengan Gambar 5 dapat dilihat lokasi tumbuh, bentuk daun, bunga, buah dan serat Calotropis gigantea hasil survei yang dilakukan oleh tim penelitian pada empat lokasi yaitu dari daerah Cilacap (pantai Penyu dan desa Panulisan), daerah Ciamis (kecamatan Cisaga), Semarang dan Yogyakarta (pantai Cemara).

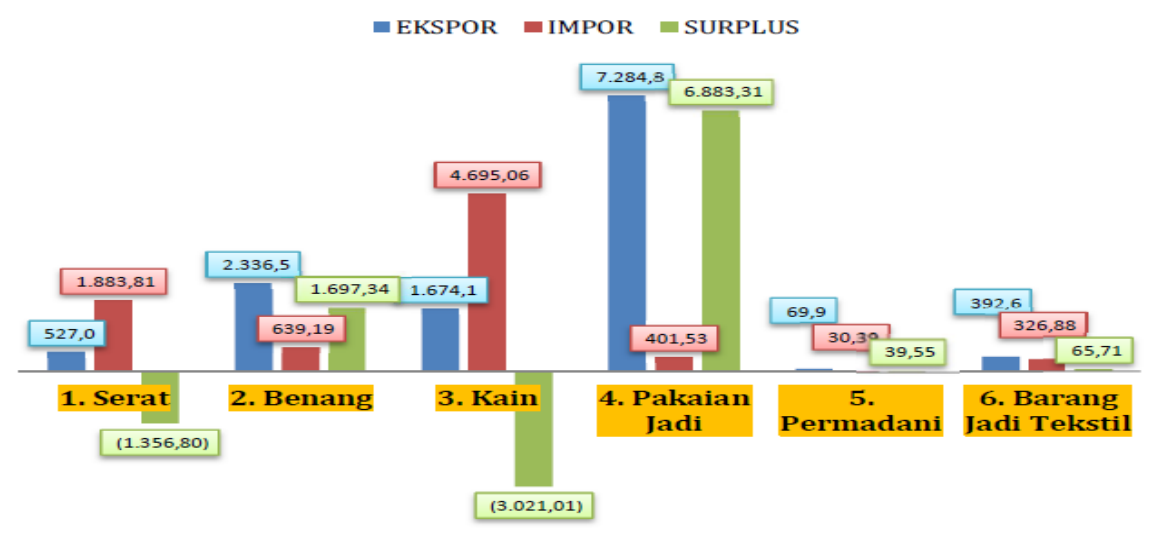

Gambar 1. Neraca perdagangan tekstil dan produk tekstil tahun 2015 (dalam ribuan USD) ${ }^{2}$ 
Karakterisasi Serat dari Tanaman Biduri (Calotropis Gigantea) dan Identifikasi Kemungkinan Pemanfaatannya Sebagai Serat Tekstil (M. Danny Sukardan, dkk)

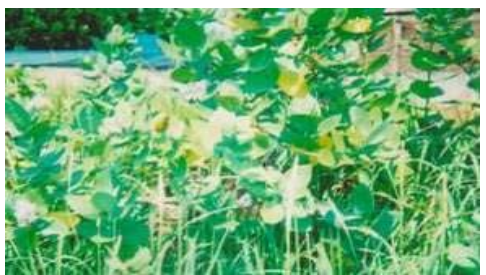

[a]

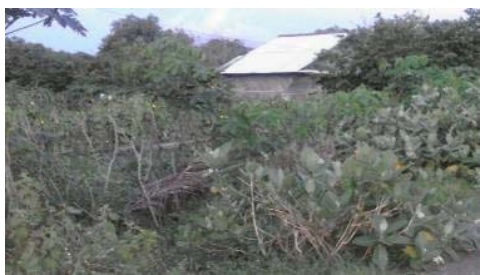

[b]

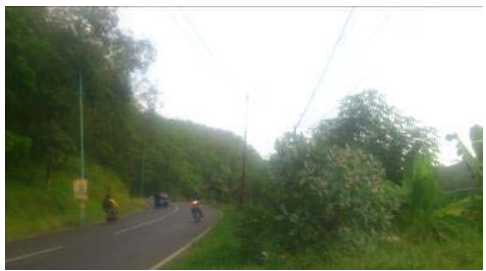

[c]

Gambar 2. Lokasi Tanaman Calotropis gigantea. [a] Ciamis; [b] Pantai Cemara, Yogyakarta; [c] Desa Panulisan, Cilacap, Jawa Tengah.

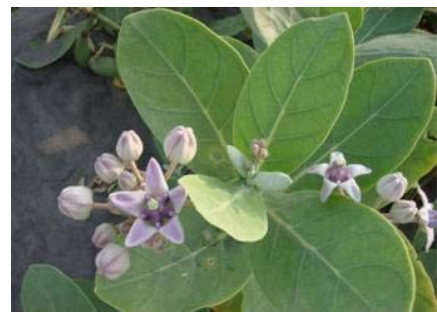

[a]

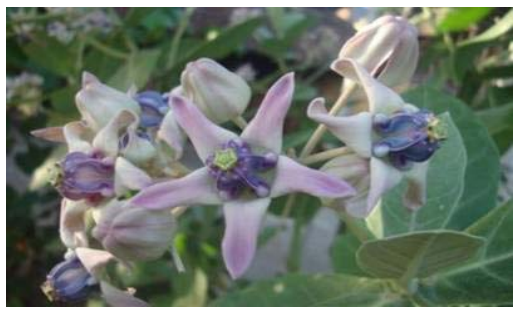

[b]

Gambar 3. Bentuk daun dan bunga Calotropis gigantea. [a] Sebagian bunga masih kuncup; [b] Bunga yang sudah mekar.

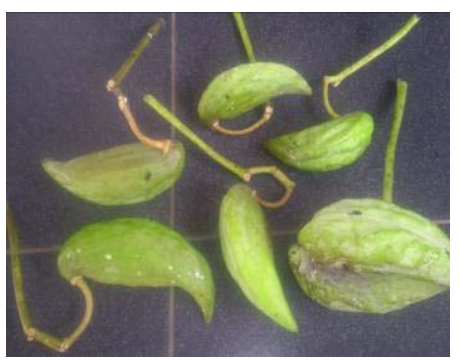

[a]

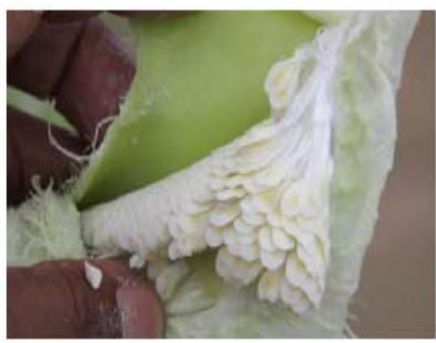

[d]

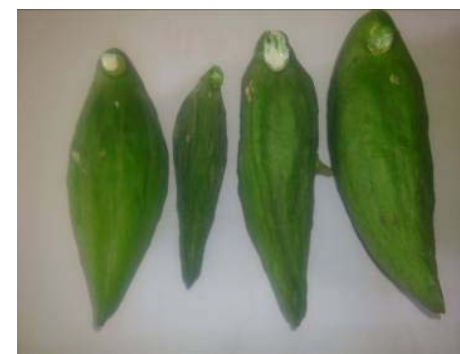

[b]

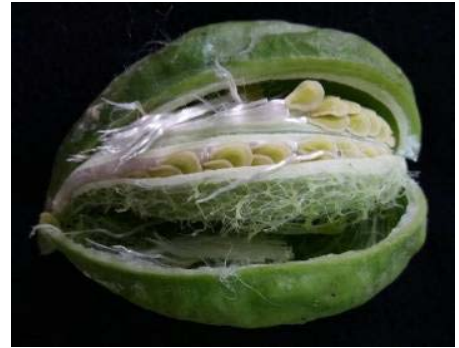

[e]

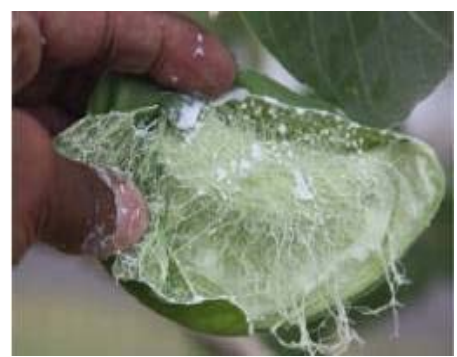

[c]

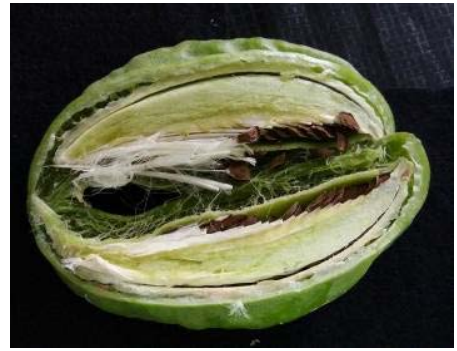

$[\mathrm{f}]$

Gambar 4. Buah dari tanaman Calotropis gigantea. [a] Buah muda; [b] Buah yang masih mengandung getah putih dan encer; [c] Buah muda belum tumbuh biji; [d] Sejumlah biji buah muda yang telah mengandung serat; [e] Buah muda yang pecah sendiri; [f] Buah berusia tua dengan biji dan serat yang matang.

Dari hasil survei yang telah dilakukan oleh tim peneliti dan wawancara dengan beberapa praktisi budidaya tanaman Calotropis gigantea, diketahui bahwa dengan mempertimbangkan lokasi tanah tertentu, tanaman ini dapat tumbuh melalui bibit berupa biji buah atau melalui penyetekan. Panen pertama kali akan berlangsung setelah tanaman berusia 6 bulan dan selanjutnya tanaman dapat dipanen secara berkala (harian atau mingguan) serta tidak mengenal musim. Tinggi maksimal tanaman Calotropis gigantea hanya $3 \mathrm{~m}$, sehingga tidak menyulitkan pada saat pemetikan secara manual, terutama jika dibandingkan dengan pohon kapuk yang dapat mencapai ketinggian lebih dari $10 \mathrm{~m}$. Satu pohon Calotropis gigantea akan menghasilkan sekurang-kurangnya 300 buah per bulan/pohon. Dengan memperhitungkan rendemen serat sebesar $8,9 \%$ dari berat kering buah $(4,59$ gram), sekurang-kurangnya dapat diperoleh sekitar 122,553 gram serat/pohon/bulan. Jika asumsi dalam 1 hektar terdapat 2.500 pohon, maka potensi serat dapat diperoleh sebanyak 306,382 $\mathrm{kg} / \mathrm{bulan} / \mathrm{Ha}$ 
(3,676 ton/Ha/tahun). Produktivitas tanaman Calotropis gigantea dinilai lebih baik dibandingkan pohon kapuk, yang produksi rata-ratanya hanya 500 $\mathrm{kg} / \mathrm{Ha} /$ tahun (tumpang sari dengan pohon kakao), dengan panen pertama baru pada tahun ke 5. Meski potensi pengembangan Calotropis gigantea cukup menjanjikan, namun belum ada petani, instansi atau lembaga yang berminat atau telah membudidayakan tanaman ini secara berkelanjutan. Hal ini kemungkinan karena belum adanya jaminan pangsa pasar yang berkelanjutan pada industri hilir.

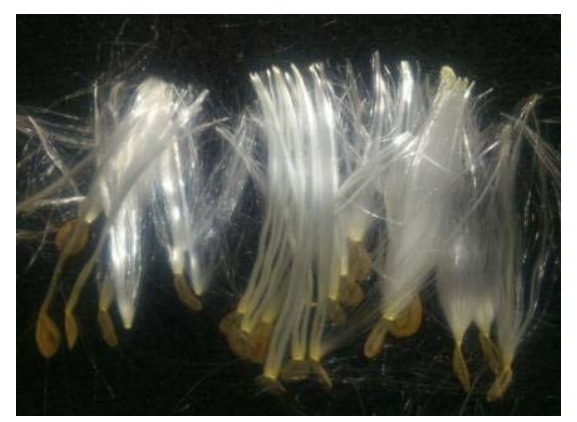

Gambar 5. Berkas serat pada biji buah (1 biji mengandung lebih dari 600 helai serat)

Beberapa kajian dan penelitian mengenai Calotropis gigantea yang telah dilakukan baik oleh perseorangan maupun lembaga/institusi riset di bidang kesehatan, industri tekstil dan industri terkait lainnya diantaranya sebagai berikut ini.

- Pemanfaatan serat dari kulit batang dan biji sebagai produk komposit. ${ }^{10,11}$ Secara morfologis serat kulit batang lebih panjang dan ramping, sedangkan serat dari biji lebih pendek dan lebar. Komposisi selulosa dari serat kulit batang lebih banyak dari pada serat biji, namun kandungan lignin serat kulit batang lebih rendah. ${ }^{12}$ Material komposit yang mengandung serat Calotropis gigantea memiliki kekuatan tarik lebih baik daripada material komposit tanpa isian serat. Yeremias M. Pell, ${ }^{13}$ menjelaskan bahwa kekuatan tarik material komposit berisi serat dipengaruhi oleh volume fraksi bahan resinnya. Reddy, N dan Yang, Y, ${ }^{14}$ memiliki kesimpulan bahwa serat Calotropis gigantea dengan berat jenis rendah akan dapat menghasilkan material komposit yang ringan dan lebih baik kualitasnya (kekuatan dan inisial modulusnya).

- Pemanfaatan serat dari biji buah Calotropis gigantea sebagai penyerap minyak juga telah dilakukan oleh Yian Zheng dkk. ${ }^{15}$ Yian Zheng, dkk menjelaskan bahwa serat Calotropis gigantea memiliki sifat hidrofobik dan oleofilik yang menakjubkan, memiliki daya apung yang baik, kapasitas daya serap minyak yang baik, dapat dipakai berulang kali pada proses pemisahan minyak dari air secara efektif. Penelitian serupa yang juga dilakukan oleh Yian Zheng, dkk ${ }^{16}$ menyatakan bahwa kapasitas serat Calotropis gigantea dalam menyerap minyak dapat mencapai 47 hingga 87 kali lipat dari berat bahan serat tersebut.

- Xue Yang, $\mathrm{dkk}^{17}$ melalui hasil penelitiannya menyatakan bahwa moisture content serat Calotropis gigantea (serat Akund, India) sedikit lebih rendah dari pada serat kapuk, namun daya serap terhadap uap airnya sama dengan serat kapuk. Serat akan mudah/cepat melepaskan kandungan uap air/cairan dan lambat dalam proses penyerapan. Proses pelepasan/penguapan uap air pada serat akan lebih cepat dari pada serat kapas dan sama seperti serat kapuk, akan tetapi kecepatan penyerapannya sangat lambat jika dibandingkan serat kapas.

- Pada proses pencelupan/pewarnaan Calotropis gigantea menggunakan tiga jenis zat warna reaktif, Qin Chen, $\mathrm{dkk}^{18}$ menyatakan bahwa serat Calotropis gigantea sangat sulit untuk diwarnai, karena kadar selulosanya lebih rendah dari pada serat kapas. Begitupula halnya dengan kerataan dan ketahanan luntur warnanya masih rendah jika dibandingkan dengan serat kapas.

- Hasil kajian (review) yang telah dilakukan oleh Sanaz Hassanzadeh dan Hossein Hasani ${ }^{19}$ memberikan beberapa kesimpulan bahwa: serat Calotropis gigantea sulit untuk dipintal karena seratnya bersifat kaku (serat hollow), licin dan mulurnya rendah, modulus inisial yang tinggi mengindikasikan serat ini sangat sesuai untuk keperluan tekstil teknik. Pada proses pemintalan di mesin carding akan timbul banyak flying waste dikarenakan rendahnya gaya kohesi antar serat. Serat Calotropis gigantea masih memiliki kandungan uap air (moisture regain/content) yang tinggi sekitar 8\%. Bentuk morfologi yang berrongga (hollow) mengindikasikan bahwa serat ini dapat dibuat produk pakaian yang nyaman (comfort). Serat ini memiliki potensi untuk dijadikan sebagai material isolator termal dan peredam suara. Sifatnya yang hidrofobik menjadikan serat tersebut sangat sesuai sebagai material penyerap minyak.

Beberapa tinjauan pustaka yang telah dipaparkan tersebut menunjukkan bahwa tanaman perdu Calotropis gigantea yang terdapat di berbagai belahan dunia ini memiliki banyak potensi untuk diaplikasikan menjadi berbagai produk akhir, khususnya produk manufaktur di bidang tekstil teknik dan produk teknik lain. Namun berdasarkan pengamatan penulis, tanaman Calotropis gigantea di Indonesia masih luput dari perhatian masyarakat maupun pemerintah, sehingga belum ada langkah konkrit untuk memanfaatkannya secara optimal. Oleh karena itu untuk memperoleh gambaran potensi pemanfaatan tanaman Calotropis gigantea, maka dilakukan penelitian untuk mengkarakterisasi sifat serat berdasarkan morfologi, sifat kimia, fisika dan mekaniknya serta uji pemintalan, sehingga 
Karakterisasi Serat dari Tanaman Biduri (Calotropis Gigantea) dan Identifikasi Kemungkinan Pemanfaatannya Sebagai Serat Tekstil (M. Danny Sukardan, dkk)

dapat dilakukan identifikasi kemungkinan pemanfaatannya sebagai bahan baku serat tekstil.

\section{METODE}

\section{Bahan yang digunakan}

Serat Calotropis gigantea yang digunakan pada penelitian ini diperoleh dari Semarang. Serat diambil dari buah matang yang berusia \pm 6 bulan. Kematangan buah ditandai dengan ujung buah yang telah pecah dan biji buah yang berwarna hitam. Pengambilan serat dilakukan secara manual dengan memisahkan terlebih dahulu serat dari biji buahnya.

\section{Peralatan yang digunakan}

Mesin yang digunakan adalah mesin mini lab spinning MESDAN untuk uji kemampuan proses pemintalan serat Calotropis gigantea.

\section{Pengamatan dan pengujian}

a. Pengamatan dimensi, berat buah, biji, kulit, daging serta rendemen serat terhadap 10 sampel buah Calotropis gigantea kering.

b. Pengamatan morfologi serat Calotropis gigantea secara melintang dan membujur menggunakan Scanning Electron Microscope (SEM) merek JEOL JSM-6510/LV/A/LA.

c. Pengujian komponen kimia serat Calotropis gigantea untuk mengetahui kandungan selulosa dan zat non selulosa lainnya.

d. Pengujian kadar air (moisture regain dan moisture content).

e. Pengujian daya serap minyak dan daya serap air.

f. Pengujian sifat fisika serat meliputi panjang serat, kehalusan, indeks kedewasaan, SCI (Spinning Consistency Index), indeks serat pendek, indeks keseragaman, mulur, kekuatan per berkas, tingkat kecerahan dan derajat kekuningan.

g. Pengujian kemampuan proses pemintalan $100 \%$ serat Calotropis gigantea menggunakan mesin mini lab spinning MESDAN.

h. Pengujian karakteristik benang $100 \%$ Calotropis gigantea meliputi nomor benang (SNI ISO 2060 - 2010), kekuatan per helai dan mulur (SNI 7650 - 2010) serta antihan per inci (SNI ISO $17202-2010)$.

\section{HASIL DAN PEMBAHASAN \\ Dimensi dan rendemen serat}

Pada Tabel 1 dapat dilihat hasil pengamatan panjang serat, berat masing-masing komponen dan rendemen serat pada 10 sampel buah kering Calotropis gigantea. Data pada Tabel 1 tersebut menunjukkan bahwa rendemen serat yang terkandung pada buah tanaman Calotropis gigantea masih lebih besar $(8,9 \%)$ jika dibandingkan rendemen serat alam lain seperti rami $(2,5 \%-3 \%)$ dan nanas $(1 \%-2 \%)$, meski masih lebih rendah jika dibandingkan kapas $(30 \%-40 \%)$ dan kapuk (20\%).

\section{Morfologi serat Calotropis gigantea}

Identifikasi penampang serat Calotropis gigantea secara melintang dan membujur dilakukan menggunakan Scanning Electron Microscope (SEM) seperti yang dapat dilihat pada Gambar 6. Gambar 6a dan 6b menyajikan tampilan penampang membujur serat Calotropis gigantea yang tampak rata (licin). Penampang serat yang rata dan licin mengindikasikan permukaan serat Calotropis gigantea memiliki sifat friksi yang rendah, terutama jika dibandingkan dengan serat alam lainnya seperti kapas (memiliki efek konvolusi), serat wol (dengan efek bergerigi) dan serat-serat tekstil lain yang memiliki kontur permukaan tertentu. ${ }^{20}$ Permukaan serat yang licin akan sangat berpengaruh pada saat proses pemintalan. Permukaan serat yang licin berpotensi mengakibatkan efek selip yang diiringi dengan terjadinya efek floating (pada saat pelurusan dan pensejajaran serat di mesin drawing) dan akan sering putus saat pembuatan roving dan benang, karena gaya friksi antar seratnya yang rendah.

Tabel 1. Dimensi, berat dan rendemen serat dari buah Calotropis gigantea kering

\begin{tabular}{lc}
\hline \multicolumn{1}{c}{ Aspek } & Besaran \\
\hline Panjang buah & $6,9 \mathrm{~cm}$ \\
Lebar/Diameter buah & $2,5 \mathrm{~cm}$ \\
Berat buah total & $4,59 \mathrm{gram}$ \\
Berat kulit buah & $3,12 \mathrm{gram}$ \\
Berat daging buah & 0,11 gram \\
Berat biji buah & 0,95 gram \\
Berat serat/buah & 0,41 gram (rendemen \\
& serat $\pm 8,9 \%)$ \\
\hline
\end{tabular}

Penampang melintang serat Calotropis gigantea berstruktur hollow (berongga) seperti yang diperlihatkan oleh Gambar 6c, 6d, 6e dan 6f. Struktur hollow menjadikan serat tersebut memiliki berat jenis yang sangat ringan (apparent density) dan cenderung lebih kaku jika dibandingkan serat kapas atau serat lain yang penampang melintangnya masif (tidak memiliki rongga udara). Penampang hollow seperti itu juga dimiliki oleh serat kapuk (Gambar 7).

Diameter luar serat Calotropis gigantea memiliki rentang antara $15 \mu \mathrm{m}-26 \mu \mathrm{m}$, tebal dinding serat antara $0,8 \mu \mathrm{m}-2 \mu \mathrm{m}$, volume hollow antara 92,3\% - 94,7\%. Dimensi serat Calotropis gigantea tersebut relatif hampir sama dengan dimensi serat kapuk. Serat kapuk yang diamati pada penelitian ini memiliki rentang diameter luar antara $10 \mu \mathrm{m}-18 \mu \mathrm{m}$, tebal dinding antara $0,6 \mu \mathrm{m}-1,3 \mu \mathrm{m}$ dan volume hollow antara 92,8\% - 94,0\%. Volume hollow yang besar (>90\%) pada serat Calotropis gigantea mengindikasikan bahwa serat tersebut 
memiliki densitas (berat per satuan volume) yang rendah. Ruang hollow yang terdapat di sepanjang serat dapat berfungsi sebagai media/perangkap udara atau uap air sehingga sifat serat tersebut memiliki potensi sebagai isolator termal, peredam suara, penyerap minyak, material bulky, material pengapung (bouyancy), material tahan air (water repellent) dan memungkinkan untuk dicampur dengan serat lain khususnya dalam proses pemintalan sebagai bahan baku produk pakaian jadi yang nyaman (comfort). ${ }^{21}$

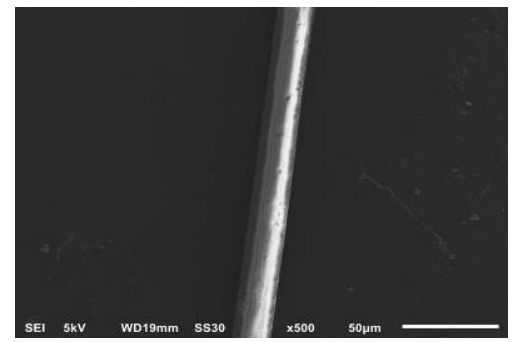

[a]

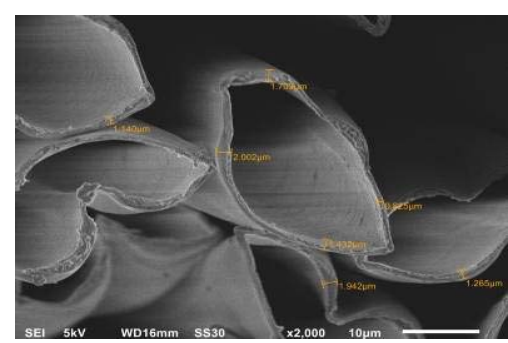

[d]

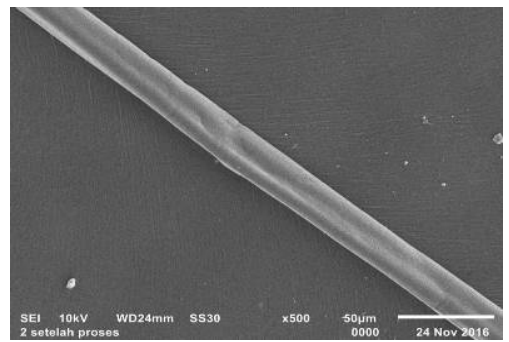

[b]

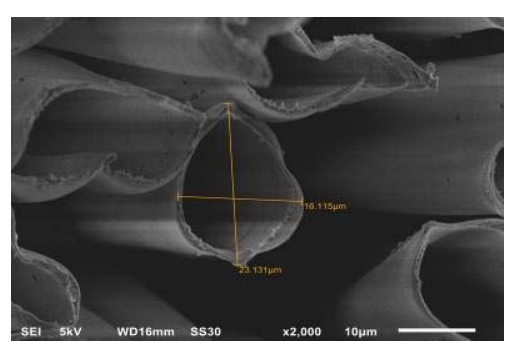

[e]

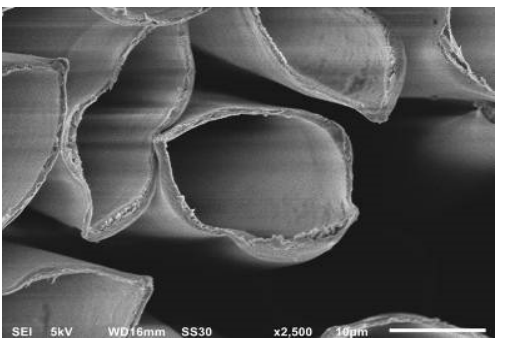

[c]

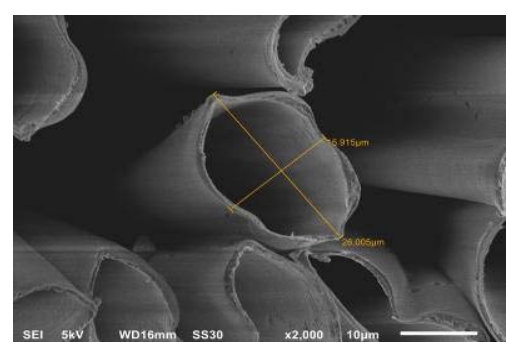

[f]

Gambar 6. Morfologi serat calotropis gigantea. [a] dan [b] Penampang membujur serat; [c] Penampang melintang serat; [d] Ukuran tebal dinding serat; [e] dan [f] Ukuran diameter luar serat.

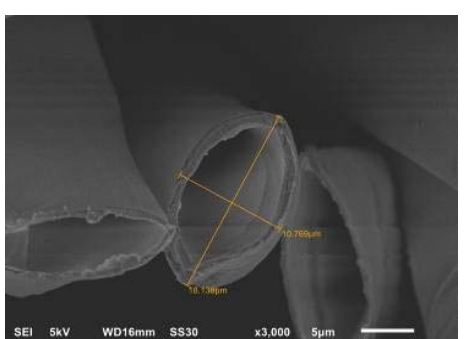

[a]

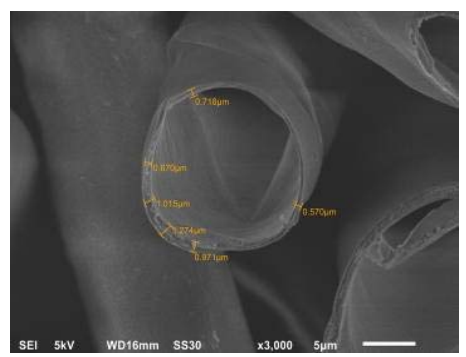

[c]

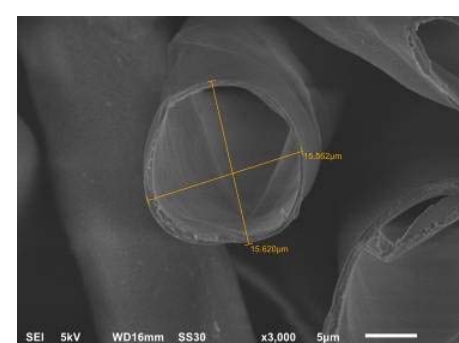

[b]

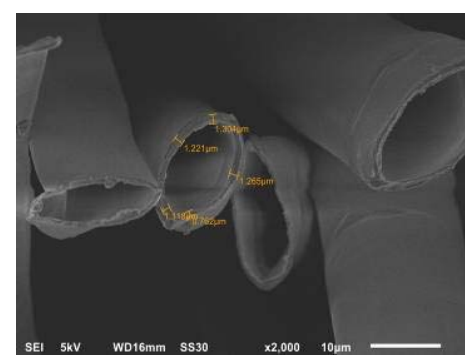

[d]

Gambar 7. Morfologi serat kapuk. [a] dan [b] Ukuran diameter luar serat; [c] dan [d] Ukuran tebal dinding serat. 
Karakterisasi Serat dari Tanaman Biduri (Calotropis Gigantea) dan Identifikasi Kemungkinan Pemanfaatannya Sebagai Serat Tekstil (M. Danny Sukardan, dkk)

Tabel 2. Kadar selulosa dan zat-zat non selulosa lainnya pada serat Calotropis gigantea, kapuk dan kapas

\begin{tabular}{|c|c|c|c|c|c|c|}
\hline Jenis Serat & $\begin{array}{c}\text { Selulosa } \\
{[\%]}\end{array}$ & $\begin{array}{l}\text { Pentosan sebagai } \\
\text { hemiselulosa [\%] }\end{array}$ & $\begin{array}{c}\text { Lignin } \\
{[\%]}\end{array}$ & $\begin{array}{c}\text { Pektin } \\
{[\%]}\end{array}$ & $\begin{array}{l}\text { Abu } \\
{[\%]}\end{array}$ & $\begin{array}{l}\text { Wax } \\
{[\%]}\end{array}$ \\
\hline \multicolumn{7}{|l|}{ Calotropis gigantea $^{22}$} \\
\hline - Semarang & $66,52-71,62$ & 36,03 & $13,45-14,08$ & - & 4,17 & - \\
\hline - Serat Akund (India) ${ }^{27}$ & 55,45 & - & 16,15 & - & - & - \\
\hline Kapuk Semarang ${ }^{22}$ & 72,86 & 33,26 & 15,84 & - & 1,74 & - \\
\hline Kapuk China ${ }^{21}$ & 64 & - & 13 & - & $1,4-3,5$ & 0,8 \\
\hline Kapas ${ }^{19}$ & $85,0-90,0$ & - & $0,7-1,6$ & - & $0,8-2,0$ & 0,5 \\
\hline
\end{tabular}

\section{Komponen kimia serat Calotropis gigantea}

Hasil uji komponen kimia serat, ${ }^{22}$ menunjukkan bahwa kadar selulosa serat Calotropis gigantea $(66,52-71,62) \%$ lebih rendah dari pada serat kapas $^{19}(85,0-90,0) \%$, akan tetapi relatif hampir sama apabila dibandingkan dengan serat kapuk $^{21,22}(64,0-72,86) \%$. Data kadar selulosa dan zat-zat non selulosa lainnya pada serat Calotropis gigantea, serat kapas dan kapuk dapat dilihat pada Tabel 2.

Jika dibandingkan dengan serat selulosa lain seperti kapas, Calotropis gigantea memiliki kadar selulosa lebih rendah serta kadar hemiselulosa dan lignin yang lebih tinggi, dengan demikian afinitas terhadap zat warnanya cukup rendah. Hal ini terjadi karena gaya antar molekul yang disebabkan oleh sebagian gugus hidroksil selulosa membentuk block dan saling melilit, sehingga molekul zat warna tidak dapat diserap secara merata. ${ }^{23}$ Adanya kandungan lignin yang tinggi merupakan ciri khas dari serat Calotropis gigantea dan serat kapuk yang menjadikan serat tersebut bersifat hidrofobik, oleofilik dan permukaannya licin.

\section{Kadar air (MC dan MR)}

Hasil pengujian kadar air (moisture content/moisture regain $)^{24,25}$ serat Calotopis gigantea dibanding serat lainnya diperlihatkan pada Tabel 3. Berdasarkan data hasil uji, Serat Calotropis gigantea memiliki kadar air yang cukup baik (MC 7,3\% dan MR 7,9\%), meski masih relatif lebih rendah jika dibandingkan serat kapas (MC $8,0 \%$ dan MR 8,5\%) serta serat Calotropis gigantea/mudar fiber yang diteliti oleh Sakthivel dan Gosh $(11,1 \%)^{26}$ dan serat Calotropis gigantealakund fiber yang diteliti Subhankar, dkk (MC 10,44\%, MR 13,8\%) ${ }^{27}$. Nilai MC dan MR yang tinggi menunjukkan bahwa serat memiliki kadar air yang cukup tinggi sehingga memiliki kenyamanan yang baik jika digunakan. Selain itu serat pun memiliki konduktivitas dan daya serap terhadap uap air yang cukup baik pula.

\section{Daya serap air dan minyak}

Meski kadar air serat Calotropis gigantea masih cukup tinggi, namun serat ini memiliki sifat hidrofobik dan oleofilik. Serat Calotropis gigantea masih tetap dapat mengapung dengan baik pada media air dan media minyak bakar (viskositas 8,24 cps) selama 5 menit. Hasil pengamatan tersebut mengindikasikan bahwa serat memiliki berat jenis (densitas) yang lebih rendah dari pada air dan minyak. Pengamatan posisi contoh uji dilanjutkan hingga 24 jam dan setelah kurun waktu tersebut serat Calotropis gigantea masih tetap mengapung di atas permukaan air dan tidak terbasahi oleh air. Meskipun setelah 24 jam serat Calotropis gigantea telah terbasahi sempurna oleh minyak namun serat masih mampu mengapung di permukaan minyak. Pengamatan posisi contoh serat dengan berat nominal 1 gram dan 3 gram pada larutan minyak dilanjutkan hingga 120 jam. Sebagai pembanding, pengamatan dilakukan pula pada serat kapuk. Pada sampel serat dengan berat nominal 1 gram, sampel serat kapuk lebih dulu tenggelam pada hitungan 43 jam, sedangkan serat Calotropis gigantea baru tenggelam pada hitungan 78 jam. Pada hitungan 120 jam, sampel serat kapuk dengan berat nominal 3 gram telah tenggelam sedangkan 3 gram sampel Calotropis gigantea belum tenggelam.

Tabel 3. Kadar air (MC/MR) serat Calotropis gigantea, kapuk dan kapas

\begin{tabular}{lcc}
\hline \multicolumn{1}{c}{ Jenis Serat } & MC (\%) & MR (\%) \\
\hline Calotropis gigantea & $\mathbf{7 , 3}$ & $\mathbf{7 , 9}$ \\
$\begin{array}{l}\text { Mudar fiber } \\
\text { (Sakthivel \& Gosh) }\end{array}$ & 11,1 & \\
Akund fiber & & \\
(Subhankar, dkk) $^{27}$ & 10,44 & 13,8 \\
Kapuk & 7,4 & 8,0 \\
Kapas & 8,0 & 8,5 \\
\hline
\end{tabular}

Daya serap air dan minyak diuji sesuai standar material penyerap minyak. ${ }^{25}$ Tabel 4 menyajikan data hasil uji daya serap air dan minyak serat Calotropis gigantea dan kapuk dengan berat sampel 1, 2, 3 gram. Data tersebut menggambarkan bahwa rata rata daya serap minyak serat Calotropis gigantea jauh lebih tinggi dibandingkan daya serap airnya yaitu rasio minyak : air 60,89 kali $(\mathrm{g} / \mathrm{g})$ dan $57,06 \mathrm{kali}\left(\mathrm{g} / \mathrm{cm}^{3}\right)$. Hal ini mengindikasikan bahwa 
serat Calotropis gigantea bersifat hidrofobik dan oleofilik. Jika dibandingkan dengan serat kapuk, sifat hidrofobik serat Calotropis gigantea jauh lebih besar dari pada serat kapuk (rata rata daya serap air serat Calotropis gigantea 0,2886 g/g dan 0,01441 $\mathrm{g} / \mathrm{cm}^{3}$ jauh lebih kecil dari serat kapuk 0,4897 g/g dan $\left.0,0156 \mathrm{~g} / \mathrm{cm}^{3}\right)$, namun sifat oleofiliknya relatif masih sama (Calotopis gigantea 17,5732 g/g dan $0,8221 \mathrm{~g} / \mathrm{cm}^{3}$, kapuk $17,9120 \mathrm{~g} / \mathrm{g}$ dan 0,8599 $\left.\mathrm{g} / \mathrm{cm}^{3}\right)$.

\section{Sifat fisika serat Calotropis gigantea}

Untuk mengetahui karakteristik berbagai sifat fisika dari serat Calotropis gigantea maka telah dilakukan pengujian menggunakan alat uji HVI Spectrum. ${ }^{28}$ Alat uji HVI Spectrum dapat mengukur lebih dari 10 jenis pengujian dalam waktu yang bersamaan. Hasil pengujian sifat fisika serat Calotropis gigantea dapat dilihat seperti pada Tabel 5.

Tabel 4. Hasil uji daya serap air dan daya serap minyak (metoda keranjang)

\begin{tabular}{|c|c|c|c|c|c|c|c|c|}
\hline \multirow{3}{*}{$\begin{array}{c}\text { Berat sampel } \\
\quad \text { (gram) }\end{array}$} & \multicolumn{4}{|c|}{ Daya Serap Air } & \multicolumn{4}{|c|}{ Daya Serap Minyak } \\
\hline & \multicolumn{2}{|c|}{ gram/gram } & \multicolumn{2}{|c|}{$\operatorname{gram} / \mathrm{cm}^{3}$} & \multicolumn{2}{|c|}{ gram/gram } & \multicolumn{2}{|c|}{ gram $/ \mathbf{c m}^{3}$} \\
\hline & $C G$ & Kapuk & CG & Kapuk & $C G$ & Kapuk & $C G$ & Kapuk \\
\hline 1 & 0,4190 & 1,025 & 0,01185 & 0,0147 & 28,1185 & 27,6425 & 0,7980 & 0,7863 \\
\hline 2 & 0,2627 & 0,197 & 0,01485 & 0,0111 & 15,0495 & 15,0253 & 0,8540 & 0,8524 \\
\hline 3 & 0,1841 & 0,247 & 0,01565 & 0,0209 & 9,5516 & 11,0681 & 0,8113 & 0,9409 \\
\hline Rata-rata & $\begin{array}{l}\frac{0,2886}{59 \%<} \\
\frac{59 \text { kapuk }}{\underline{4}}\end{array}$ & 0,4897 & $\begin{array}{l}\frac{0,01441}{92 \%<} \\
\underline{\text { kapuk }}\end{array}$ & 0,0156 & $\begin{array}{c}\frac{17,5732}{\text { Rasio thd }} \\
\text { air } \\
\underline{60,89}\end{array}$ & $\begin{array}{c}17,9120 \\
\text { Rasio thd } \\
\text { air } 36,58\end{array}$ & $\begin{array}{l}\frac{0,8221}{\text { Rasio thd }} \\
\text { air } \\
57,06 \\
\end{array}$ & $\begin{array}{c}0,8599 \\
\text { Rasio thd } \\
\text { air } \\
55,12\end{array}$ \\
\hline
\end{tabular}

Keterangan : $\mathrm{CG}=$ Calotropis gigantea , Volume keranjang : $35,34 \mathrm{~cm}^{3}$

Tabel 5. Karakteristik sifat fisika serat Calotropis gigantea dan pembandingnya

\begin{tabular}{|c|c|c|c|c|c|c|}
\hline \multirow{2}{*}{ Sifat Fisika } & \multicolumn{2}{|c|}{$\begin{array}{c}\text { Serat Calotropis gigantea } \\
\text { (Rata rata; \% CV) }\end{array}$} & \multicolumn{3}{|c|}{$\begin{array}{c}\text { Serat Kapas } \\
\text { (Rata rata; \% CV) }\end{array}$} & \multirow{2}{*}{$\begin{array}{c}\text { Serat Kapuk } \\
\text { (Rata rata; \% } \\
\text { CV) }\end{array}$} \\
\hline & $\begin{array}{c}\text { Hasil } \\
\text { Penelitian }\end{array}$ & Sumber lain & $\begin{array}{l}\text { Argentina } \\
\text { B 50798 }\end{array}$ & $\begin{array}{c}\text { Brazil } \\
\text { B 1148527 } \\
\end{array}$ & Memphis & \\
\hline Diameter , $\mu \mathrm{m}$ & $\left.15-26{ }^{*}\right)$ & $\begin{array}{l}30-50^{26} \\
12-42^{27}\end{array}$ & - & - & - & $\left.10-18 ;-{ }^{*}\right)$ \\
\hline $\begin{array}{l}\text { Kehalusan } \\
(\text { mikroner, } \mu)\end{array}$ & 2,$02 ; 0,4$ & $\begin{array}{c}2,4^{26} \\
1 \mathrm{dtex}^{27}\end{array}$ & 2,74 & 3,82 & 5,35 & 2,$02 ; 0,3$ \\
\hline Indek Kedewasaan & 0,$81 ; 0,7$ & - & 0,82 & 0,89 & 0,94 & 0,$71 ; 0,6$ \\
\hline $\begin{array}{l}\text { SCI (Spinning Consistency } \\
\text { Index) }\end{array}$ & $219 ; 5,9$ & - & 136 & 174 & 210 & $73 ; 7,1$ \\
\hline Panjang (inci) & 1,$25 ; 6,6$ & $\begin{array}{l}1,10^{26} \\
1,20^{27}\end{array}$ & 0,97 & 1,12 & 1,10 & 0,$63 ; 4,1$ \\
\hline Indek Keseragaman & 84,$0 ; 2,1$ & - & 78,2 & 79,9 & 82,3 & $74,4,00,8$ \\
\hline Indek Serat Pendek & 7,$8 ; 11,3$ & - & 14,6 & 11,7 & 10,0 & 25,$2 ; 10,9$ \\
\hline Kekuatan/berkas (g/tex) & 37,$8 ; 6,5$ & $\begin{array}{l}24,8^{26} \\
34,5^{27}\end{array}$ & 22,7 & 26,4 & 32,2 & 15,$8 ; 8,2$ \\
\hline Mulur (\%) & 3,$9 ; 3,8$ & $2,9^{26}$ & 8,3 & 8,3 & 8,0 & 3,$8 ; 8,0$ \\
\hline Rd (tingkat kecerahan) & 60,$8 ; 0,3$ & - & 63,5 & 72,0 & 74,1 & 57,$2 ; 4,0$ \\
\hline +b (derajat kekuningan) & 19,$6 ; 0,5$ & - & 10,2 & 11,9 & 9,1 & 12,$7 ; 5,0$ \\
\hline
\end{tabular}

Keterangan : ${ }^{*}$ Pengukuran menggunakan SEM

\section{Kehalusan}

Kehalusan serat (mikroner) serat Calotropis gigantea adalah 2,02 $\mu$ (2,02 mikrogram per 1 inci). Kehalusannya relatif masih sama dengan serat kapuk $(2,02 \mu)$, namun jauh lebih rendah atau lebih halus daripada serat kapas $(2,7 \mu$; $3,82 \mu$ dan $5,35 \mu)$. Semakin kecil nilai kehalusan serat, maka serat tersebut akan semakin ringan. Serat yang terlalu halus atau ringan akan menyulitkan pada saat proses pemintalannya, diantaranya pada saat proses penguraian di mesin carding cenderung akan membentuk nep, terjadi proses floating fiber pada saat proses pelurusan dan pensejajaran serat di mesin drawing dan akan 
berpotensi sering terjadi putus benang pada saat proses pembuatan roving di mesin roving/simplex maupun saat pembuatan benang di mesin ring spinning atau open end. Namun demikian, serat yang semakin halus (tanpa mempertimbangkan efek friksi) akan berbanding lurus dengan kekuatan serat per berkas, karena jumlah serat yang berkontribusi terhadap kekuatan serat per berkas lebih banyak dari pada serat yang kasar (jumlah luas permukaan serat halus lebih besar dibandingkan serat kasar).

\section{Indeks kedewasaan}

Indeks kedewasaan yang semakin tinggi menunjukkan bahwa serat tersebut makin dewasa, khususnya untuk serat kapas. Semakin tinggi nilai kedewasaan akan terlihat pada semakin tebalnya dinding serat (volume lumen semakin kecil). Indeks kedewasaan serat Calotropis gigantea $(0,81)$ relatif lebih kecil dari pada sampel serat kapas $(0,82 ; 0,89$ dan 0,94$)$, namun masih lebih tinggi dibandingkan serat kapuk $(0,71)$.

SCI (Spinning Consistency Index) secara empiris (formula) berkorelasi dengan kekuatan benang dan kelancaran proses pemintalan. Hasil SCI serat Calotropis gigantea termasuk paling tinggi (219), bahkan lebih besar dari pada contoh serat kapas (136; 174 dan 210), dan jauh lebih besar dari pada serat kapuk (hanya 73 ). Tingginya nilai SCI serat Calotropis gigantea tidak menjadi jaminan akan menghasilkan kekuatan benang yang tinggi dan tidak akan mengalami kesulitan pada proses pembuatan benang. Untuk mengetahui hingga sejauh mana daya pintal serat Calotropis gigantea, maka perlu dilakukan penelitian khusus seperti uji performa pemintalan (spinnability), dengan memperhatikan komposisi serat, nomor benang, kecepatan spindel/rotor dan faktor antihan (twist factor).

\section{Panjang serat}

Panjang serat Calotropis gigantea 1,25 inci (31,8 mm setara dengan 40/32) lebih tinggi dari pada contoh serat kapas $(0,97$ inci; 1,12 inci dan 1,10 inci) dan kapuk (0,63 inci). Nilai panjang serat Calotropis gigantea ini menjadikan serat tersebut termasuk kategori long staple fiber. ${ }^{29,30}$ Semakin panjang ukuran serat maka akan dapat dibuat benang yang lebih halus, namun hal ini belum tentu demikian adanya untuk serat Calotropis gigantea yang memiliki permukaan serat yang licin yang dapat mengurangi daya pintal seratnya.

\section{Keseragaman serat}

Keseragaman panjang serat Calotropis gigantea termasuk yang paling tinggi (84) dibandingkan sampel serat kapas $(78,2 ; 79,9$ dan
$82,3)$ dan kapuk $(74,4)$. Dalam kondisi ideal untuk serat kapas, tingginya nilai keseragaman serat akan menghasilkan benang yang lebih rata (nilai U\% yang rendah) dan jumlah ketidaksempurnaan (imperfection) thin/thick/nep per satuan panjang yang lebih sedikit.

\section{Kekuatan serat per berkas}

Kekuatan serat per berkas Calotropis gigantea termasuk yang paling tinggi $(37,8 \mathrm{~g} / \mathrm{tex})$ dibandingkan sampel serat kapas $(22,7 \mathrm{~g} / \mathrm{tex} ; 26,4$ $\mathrm{g} /$ tex dan 32,2 g/tex) dan kapuk (15,8 g/tex). Kekuatan tarik serat merupakan salah satu faktor yang menentukan terhadap kekuatan tarik benang. Namun kekuatan tarik benang tersebut juga dipengaruhi oleh faktor friksi antar serat dan keseragaman panjang seratnya.

\section{Indeks serat pendek}

Indeks serat pendek (akumulasi serat pendek) serat Calotropis gigantea termasuk paling kecil $(7,8)$ dibandingkan serat kapas $(10,0 ; 11,7$ dan $14,6)$ dan kapuk $(25,2)$. Rendahnya kandungan serat pendek ini merupakan bagian dari variasi panjang dari asal seratnya (dari biji), bukan dari variasi di dalam individu setiap biji buah. Semakin kecil kandungan serat pendek akan meningkatkan daya pintal seratnya, limbah (reused) yang sedikit dan meningkatkan kualitas benang pada proses pembuatan benang yang halus (benang combed).

\section{Mulur}

Mulur serat calotropis gigantea yang 3,9\% termasuk rendah apabila dibandingkan dengan serat kapas (sekitar $8 \%$ ) dan relatif hampir sama dengan mulur serat kapuk (3,8\%). Semakin kecil tingkat mulur serat maka akan berakibat pada rendahnya mulur benang yang akan dihasilkannya.

\section{Tingkat kecerahan warna}

Nilai Rd menunjukkan tingkat kecerahan warna serat, Nilai Rd yang semakin besar menyatakan bahwa serat tersebut secara visual tampak lebih putih dan cerah. Serat Calotropis gigantea $(\operatorname{Rd} 60,8)$ dan kapuk $(57,2)$, secara visual tampak lebih rendah cerah/putih dibanding serat kapas (Rd : 63,5; 72 dan 74,1).

\section{Derajat kekuningan}

Nilai $+b$ (derajat kekuningan) serat Calotropis gigantea menunjukkan nilai yang paling besar $(19,6)$ dibandingkan serat kapas $(9,1 ; 10,2$ dan 11,4) dan serat kapuk $(12,7)$. Hal ini menunjukkan bahwa serat Calotropis gigantea secara visual tampak lebih kuning, namun tampak lebih berkilau menyerupai serat sutera. 
Tabel 6. Data hasil uji sifat fisik benang Calotropis gigantea

\begin{tabular}{lcc}
\hline \multicolumn{1}{c}{ Jenis Uji } & Mutu hasil uji & Mutu (SNI 08-0033-2006) \\
\hline No. Benang, Tex (Ne $)$; CV (\%) & $38(15,5) ; 18,2$ & $36,9(16) ; 5$ \\
Kekuatan/helai, gram; CV \% & 129,$96 ; 12,7$ & $643 ; 18$ \\
Mulur (\%): CV (\%) & 3,$32 ; 28,8$ & - \\
Antihan/inci; CV \%) & 25,$5 ; 17,2$ & Maks. 17,6; 12 \\
Komposisi serat & $100 \%$ Calotropis gigantea & $100 \%$ Kapas \\
\hline
\end{tabular}

\section{Kemampuan proses pemintalan}

Untuk mengetahui kemampuan proses pemintalan serat Calotropis gigantea, dilakukan percobaan dengan memintal 100 gram sampel serat Calotropis gigantea menggunakan mesin mini lab spinning Mesdan. Urutan proses pemintalan adalah diawali dengan mesin opening (trash analyzer) $\rightarrow$ roller card (carding) $\rightarrow$ stirolab (drawing \& roving) $\rightarrow$ ring spinning. Data hasil uji sifat fisik benang dapat dilihat pada Tabel 6 . Nomor benang yang dihasilkan pada uji pemintalan serat Calotropis gigantea 100\% ini termasuk kategori benang kasar $\left(\mathrm{Ne}_{1} 15,5\right)$, namun kekuatan benang yang dihasilkan termasuk rendah sekali $(129,96$ gram) dengan $\mathrm{CV} \%$ tinggi (18). Namun demikian jumlah antihan per inci 25,5 dengan CV \% 17,2 termasuk tinggi sehingga tidak memenuhi standar minimal yang dipersyaratkan ${ }^{31}$. Secara ideal untuk nomor benang $\mathrm{Ne}_{1} 15,5$, sebaiknya menggunakan ketetapan antihan (twist multiplier, $\alpha$ ) $=4$. Secara teoritis jumlah antihan per inci menggunakan formula $\alpha \times \sqrt{ } \mathrm{Ne}_{1}=4 \times \sqrt{15,5}=15,75$. Sementara data hasil uji jumlah antihan per inci menunjukkan nilai 25,5 yang relatif jauh lebih besar dari jumlah antihan per inci teoritis $(15,75)$. Berdasarkan pengamatan, benang yang dihasilkan tersebut memiliki kekurangan dalam hal keseimbangan antihannya yang nantinya dapat berdampak pada timbulnya efek snarling (melintir).

Untuk memperoleh gambaran performa daya pintal serat Calotropis gigantea secara komprehensif, perlu dilakukan serangkaian percobaan kemampuan proses pembuatan benang (khususnya pada sistem pemintalan kapas) dengan memperhatikan faktor-faktor sebagai berikut :

- Variasi nomor benang yang akan dibuat

- Jenis serat lain, sebagai bahan campuran (blending)

- Variasi kecepatan spindel (ring spinning)

- Variasi kecepatan rotor (open end)

- Variasi nomor traveler (ring spinning)

- Variasi ketetapan antihan

- Variabel variabel lainnya pada proses persiapan pemintalannya.

Resiko/hambatan proses pemintalan yang mungkin terjadi diantaranya adalah lapping, floating dan cracking fiber, putus web dan sliver, dan meningkatnya intensitas terjadinya putus benang $^{26}$. Sakthivel dan Ghosh telah berhasil membuat benang $\mathrm{Ne}_{1} 30$ menggunakan campuran serat Calotropis gigantea/kapas dengan variasi komposisi 75/25/; 67/33; 50/50; 33/67 dan 0/100. Hasil uji kekuatan tarik dan mulur benang pada berbagai komposisi campuran serat tersebut adalah $(14,1-16)$ gram/tex untuk kekuatan tarik, dengan mulur $(6,4-7,2) \%$. Proses pencampuran serat dilakukan pada mesin blowing (opening) dan proses penguraian dan pelurusan/pensejajaran serat dilakukan 2 kali proses masing masing di mesin carding dan drawing; kecepatan proses dipertahankan pada kecepatan yang lambat pada setiap tahapan proses pemintalan, dengan nomor roving dibuat dengan $\mathrm{Ne}_{1} 2,2$.

\section{KESIMPULAN}

Berdasarkan hasil penelitian yang telah dilakukan, maka dapat diambil beberapa kesimpulan sebagaimana berikut ini.

1. Serat Calotropis gigantea atau yang dikenal dengan nama biduri memiliki morfologi berbentuk hollow (berrongga) dengan volume hollow $92,3-94,7 \%$ dan rendemen serat $8,9 \%$ dari berat buah.

2. Kandungan selulosa serat Calotropis gigantea sebesar 66,52 - 71,62 \% relatif hampir sama dengan serat kapuk semarang $(72,86 \%)$, namun lebih besar dibandingkan kapuk china (64\%). Secara keseluruhan kandungan selulosanya masih jauh lebih rendah dibandingkan serat kapas $(85,0-90,0) \%$.

3. Kadar lignin serat Calotropis gigantea cukup tinggi (13,45 - 14,08 \%); kadar air (MC 7,3\%; MR 7,9\%); rasio daya serap minyak : air 60,89 kali $(\mathrm{g} / \mathrm{g})$ dan $57,06 \mathrm{kali}\left(\mathrm{g} / \mathrm{cm}^{3}\right)$.

4. Sifat fisika Calotropis gigantea yaitu panjang \pm 1,25 inchi; kerataan panjang 84,0; kekuatan per berkas 37,8 g/tex; efek kilau tinggi (+b 19,6); indeks serat pendek 7,8 ; mulur rendah $(3,9 \%)$; ringan dan halus $(2,02 \mu)$; kaku; permukaan licin; mengapung di air dan minyak (buoyant).

5. Hasil uji pemintalan $100 \%$ Calotropis gigantea menunjukkan bahwa kualitas benang masih di 
Karakterisasi Serat dari Tanaman Biduri (Calotropis Gigantea) dan Identifikasi Kemungkinan Pemanfaatannya Sebagai Serat Tekstil (M. Danny Sukardan, dkk)

bawah standar mutu benang ring tenun (carded) kapas $100 \%$ (SNI 08-0033-2006).

6. Berdasarkan hasil pengamatan dan penelitian, karakteristik morfologi hollow pada serat Calotropis gigantea menjadikannya berpotensi untuk dijadikan insulator termal maupun suara. Kandungan udara terperangkap dalam serat hollow Calotropis gigantea menjadikannya ringan dan buoyant sehingga berpotensi untuk dijadikan material pengapung. Sifat hidrofobik dan oleofilik serat Calotropis gigantea dapat dimanfaatkan untuk menjadikannya sebagai material penyerap tumpahan minyak.

7. Produktivitas hasil serat Calotropis gigantea cukup tinggi dengan perkiraan produksi serat \pm 3,6 ton/Ha/tahun.

\section{PUSTAKA}

1. Bappenas, Peraturan Presiden No. 7 tahun 2005. (2013).

2. Direktorat Jenderal Industri Kimia Tekstil dan Aneka, Kementerian Perindustrian, Laporan Kajian Industri Serat Nasional (2016).

3. http://www.apidkijakarta_weekly.com/berita/bah an-baku-tekstil-bersumber-dari-impor; diakses tgl 15 Nopember 2016.

4. Heyne, K., Tanaman Berguna Indonesia, 4 : 87. (1988)

5. Palejkar,C.J., Palejkar, J.H., Patel, M.A., Patel, A.J. A Comprehensive Review on Plant Calotropis Gigantea. International Journal of Institutional Pharmacy and Life Sciences, 2(2): 463-470. (2012).

6. www.tanobat.com>biduri; diakses tanggal 30 Nopember 2016.

7. Nasser, R.A., Al-mefarrej, H.A., Khan, P.R., et al. Technological properties of Calotropis procera (AIT) wool and its relation to utilizations. Am Eurasian J Agric Environ Sci., 12: 5-16. (2012).

8. Theeraraj, G. An investigation into the feasibility of using Calotropis gigantea (Flower of Love) as a source of fiber for textile production. Master Thesis. Faculty of Environment and Resource Studies, Mahidol University in Bangkok, Thailand. (1983).

9. Vadlapudi, V., Behara, M., Kaladhar, D.S.V.G.K, et al., Antimicrobial profile of crude extracts Calotropis procera and Centella asiatica against some important pathogens. Ind $J$ Sci Tech, 5: 3132-3136 (2012).

10. Ashori, A., Bahreni, Z., Evaluation of Calotropis gigantea as a Promising Raw Material for Fiber- reinforced Composite. Journal of Composite Materials, 43(11) : 1297-1304 (2009).

11. Karthik, T., Ganesan, P. Development of Ecofriendly Textile Composites from Calotropis Gigantea Bast Fiber. International Journal of General Engineering and Technology (IJGET), 1 (1) : 26-43, (2012).

12. Dilli Babu, G., Sivaji Babu, K., and Nanda Kishore, P. Tensile and Wear Behavior of Calotropis Gigantea Fruit Fiber Reinforced Polyester Composites. Procedia Engineering, 97 : 531-535, (2014).

13. Yeremias, M.P., Pengaruh Fraksi Volume terhadap Karakterisasi Mekanik Green Composites Widuri-Epoxy. Seminar Nasional Sains dan Teknik 2012 (SAINSTEK 2012), 1-10 (2012).

14. Reddy, N., and Yang, Y. Non-traditional lightweight polypropylene composites reinforced with milkweed floss, Polym. Int., 59: 884-890 (2010).

15. Zheng, Y., Zhu, Y.F., Wang, A., Huimin, H. Potential of Calotropis gigantea fiber as an absorbent for removal of oil from water : Industrial Crops and Products. Chemical Engineering Journal, 295 : 477-483 (2016).

16. Zheng, Y., Cao, E., Zhu, Y.F., Wang, A., Huimin, H., Perfluorosilane treated Calotropis gigantea fiber: Instant hydrophobic-oleophilic surface with efficient oil-absorbing performance. Chemical Engineering Journal, 295 : 477-483 (2016).

17. Yang, X., Huang, L., Cheng, L., and Yu, J. Studies of Moisture Absorption and Release Behaviour of Akund Fiber. Advances in Mechanical Engineering, 23 1-4, (2012).

18. Chen, Q., Zhao, T., Wang, M., and Wang, J. Studies of the fibre structure and dyeing properties of Calotropis gigantea, kapok and cotton fibres. Color. Technol., 129 : 448-453 (2013).

19. Hassanzadeh, S., and Hasani, H., A Review on Milkweed Fiber Properties as a High-Potential Raw Material in Textile Applications. Journal of Industrial, 45 (2) : 1-25 (2015).

20. Smole, S.M., Hribernik, S., Kleinschek, K.S., and Kreže, T. Plant Fibres for Textile and Technical Applications, Advances in Agrophysical Research, chapter 15 (2013).

21. Meiwu, S., Xiao, H., and Yu, W. The Fine Structure of the Kapok Fiber. Textile Research Journal, 80 (2) : 159-165. (2010).

22. SNI $0444: 2009$, Cara uji kadar selulosa alfa, beta dan gamma. (2009).

23. Du, Q., and Chen, Y. R \& D Status and Countermeasures of Natural Functional Kapok 
Fiber. Advanced Materials Research, 796 : 199-200 (2013).

24. SNI 8100 : 2015, Tekstil - Cara uji kadar lembab (moisture content atau moisture regain) (2015).

25. Japan Maritime Safety Board, The Standard of Oil Sorbent.

26. Sakthivel, J.C., and Ghosh, A. Extraction, Properties and Spinability of Mudar Fibres (Calotropic gigantea). Industria Textila, 60 (1) : 1114 (2009).

27. Subhankar, M., Mohapatra, H.S., Chatterjee, A. New generation natural fiber - akund. Melliand International 1 : 22-24 (2014).
28. SNI 7881 : 2013, Tekstil - Serat kapas - Cara uji pengukuran sifat fisika menggunakan high volume instrument (HVI) (2013)

29. USDA, Universal standard high volume instrument for HVI testing of upland cotton "long/strongth). (2016).

30. Data hasil uji penyusunan standar mutu serat kapas (2016).

31. SNI 08 - 0033 : 2006, Benang Ring Tunggal kapas (2006). 